\title{
Upper-plate structure in Ecuador coincident with the subduction of the Carnegie Ridge and the southern extent of large mega-thrust earthquakes
}

\author{
Colton Lynner ${ }^{\oplus},{ }^{1,2}$ Clinton Koch, ${ }^{1}$ Susan L Beck, ${ }^{1}$ Anne Meltzer, ${ }^{3}$ \\ Lillian Soto-Cordero ${ }^{\oplus},{ }^{3}$ Mariah C. Hoskins, ${ }^{3}$ Josh C. Stachnik, ${ }^{3}$ Mario Ruiz, ${ }^{4}$ \\ Alexandra Alvarado, ${ }^{4}$ Philippe Charvis, ${ }^{5}$ Yvonne Font, ${ }^{5}$ Marc Regnier, ${ }^{5}$ \\ Hans Agurto-Detzel ${ }^{\oplus}, 5$ Andreas Rietbrock ${ }^{6}$ and Robert W. Porritt ${ }^{7}$ \\ ${ }^{1}$ Department of Geosciences, University of Arizona, Tucson, AZ 95721,USA. E-mail: clynner@udel.edu \\ ${ }^{2}$ Department of Earth Sciences, University of Delaware, Newark, DE 19716, USA \\ ${ }^{3}$ Department of Earth and Environmental Sciences, Lehigh University, Bethlehem, PA 18015, USA \\ ${ }^{4}$ Instituto Geofisico, Escuela Politecnica Nacional, Quito, 170525, Ecuador \\ ${ }^{5}$ Université Côte d'Azur, IRD, CNRS, Observatoire de la Côte d'Azur, Géoazur, 06304, Nice, France \\ ${ }^{6}$ Karlsruhe Institute of Technology, Geophysical Institute, Karlsruhe, 76187, Germany \\ ${ }^{7}$ University of Texas, Institute for Geophysics, Austin, TX 78758, USA
}

Accepted 2019 December 5. Received 2019 December 5; in original form 2019 April 29

\begin{abstract}
SUMMAR Y
The Ecuadorian convergent margin has experienced many large mega-thrust earthquakes in the past century, beginning with a 1906 event that propagated along as much as $500 \mathrm{~km}$ of the plate interface. Many subsections of the 1906 rupture area have subsequently produced $M_{\mathrm{w}} \geq 7.7$ events, culminating in the 16 April 2016, $M_{\mathrm{w}} 7.8$ Pedernales earthquake. Interestingly, no large historic events $M_{\mathrm{w}} \geq 7.7$ appear to have propagated southward of $\sim 1{ }^{\circ} \mathrm{S}$, which coincides with the subduction of the Carnegie Ridge. We combine data from temporary seismic stations deployed following the Pedernales earthquake with data recorded by the permanent stations of the Ecuadorian national seismic network to discern the velocity structure of the Ecuadorian forearc and Cordillera using ambient noise tomography. Ambient noise tomography extracts $V_{S v}$ information from the ambient noise wavefield and provides detailed constraints on velocity structures in the crust and upper mantle. In the upper $10 \mathrm{~km}$ of the Ecuadorian forearc, we see evidence of the deepest portions of the sedimentary basins in the region, the Progreso and Manabí basins. At depths below $30 \mathrm{~km}$, we observe a sharp delineation between accreted fast forearc terranes and the thick crust of the Ecuadorian Andes. At depths $\sim 20 \mathrm{~km}$, we see a strong fast velocity anomaly that coincides with the subducting Carnegie Ridge as well as the southern boundary of large mega-thrust earthquakes. Our observations raise the possibility that upper-plate structure, in addition to the subducting Carnegie Ridge, plays a role in the large event segmentation seen along the Ecuadorian margin.
\end{abstract}

Key words: Crustal imaging; Seismic noise; Crustal structure.

\section{IN T RODUCTION}

The Ecuadorian convergent margin has developed from the persistent subduction of the Nazca Plate beneath continental South America at a current rate of $\sim 58 \mathrm{~mm} \mathrm{yr}^{-1}$ (e.g. Kendrick et al. 2003). This convergence has led to the formation of the high mountains of the Ecuadorian Andes and the accretion (or the addition) of many oceanic terranes into the forearc and Cordillera (Fig. 1; e.g. Kerr et al. 2002; Jaillard et al. 2004; Luzieux et al. 2006; van Melle et al. 2008). Previous studies have shown that the majority of the accreted Ecuadorian terranes are derived from oceanic plateaus and island arcs (e.g. Kerr et al. 1996; Reynaud et al. 1999; Kerr \& Tarney 2005; Luzieux et al. 2006). These accretionary blocks are separated by major faults that run roughly parallel to the margin (Fig. 1).

The forearc region is comprised of several tectono-stratigraphic regions and has been the focus of many studies (e.g. Jaillard et al. 2004; Kerr \& Tarney 2005; Luzieux et al. 2006 and references therein). We primarily focus here on the forearc. Since the forearc is heavily sedimented, it is difficult to assess the affinities of the 

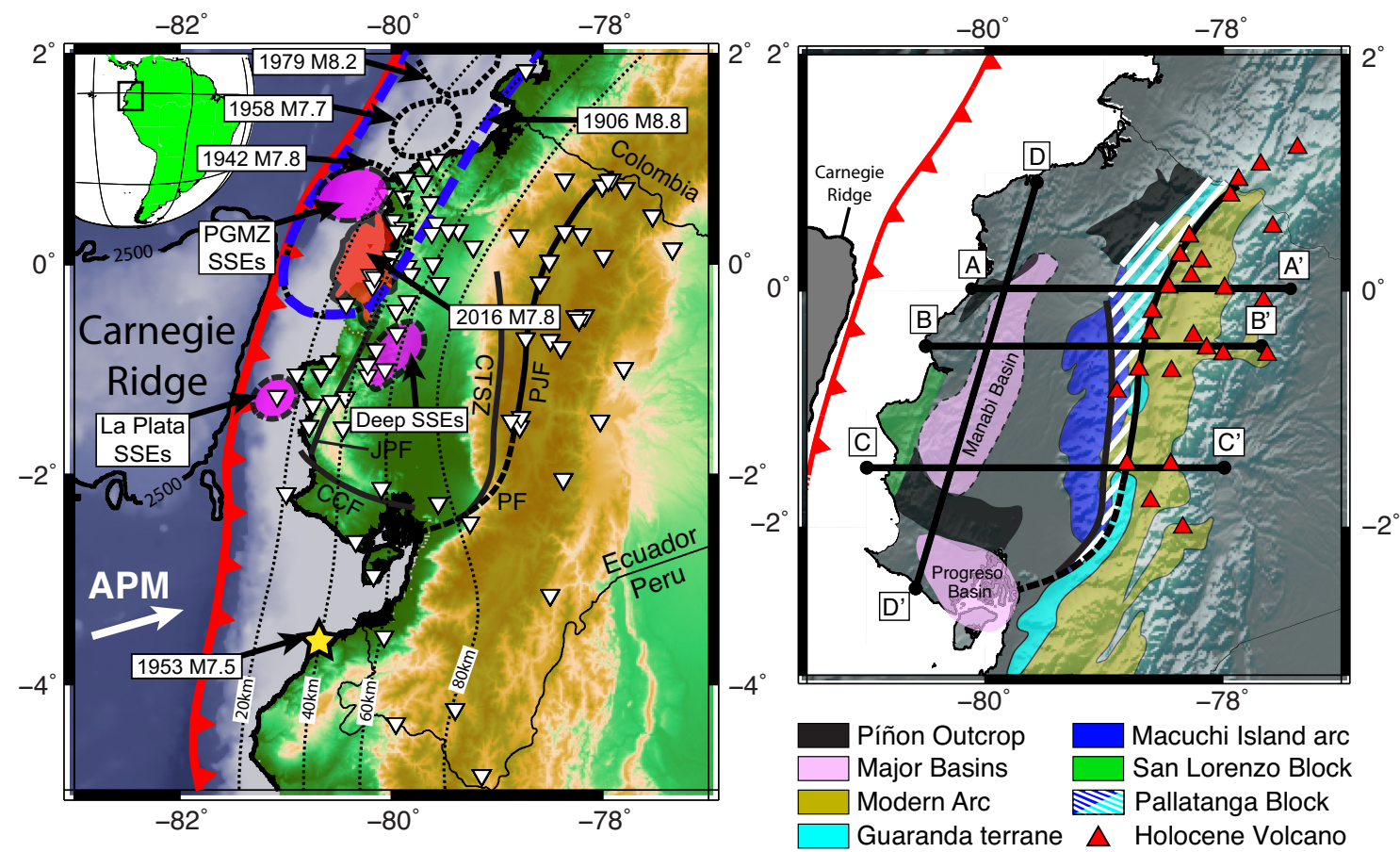

Figure 1. Left-hand panel: map of Ecuador showing all stations used in this study (white triangles); approximate aftershock area of the 1906 event (dashed blue ellipse); simplified aftershock areas of other large ( $\left.M_{\mathrm{w}} \geq 7.7\right)$ mega-thrust events prior to 2016 as estimated by aftershock studies (dashed black ellipses; Kanamori and McNally 1982; Beck and Ruff 1984; Swenson and Beck 1996); high slip region determined for the 2016, Pedernales earthquake (red patch; Nocquet et al. 2017); the region of the La Plata SSEs, the deep SSEs, and the PGMZ SSEs (pink ellipses; Vallée et al. 2013; Rolandone et al. 2018; Segovia et al. 2018; Vaca et al. 2018); the location of the $1953 M_{\mathrm{W}} 7.5$ event (gold star; International Seismological Centre 2016); the Carnegie Ridge; and major fault systems CCF: Chongón-Colonche Fault; CTSZ: Chimbo-Toachi Shear Zone; CPFZ: Calacalí-Pujilí Fault Zone; JPF: Jipijapa Fault; PJF: Pujili fault system; PF: Pallatanga Fault system. (right) Map of the tectonic blocks, accreted terranes, and basins in Ecuador that we discuss in this study (e.g. Jaillard et al. 2009). Active Holocene volcanoes are shown as red triangles. Slab contours are from Slab2 (Hayes et al. 2018). Cross-sections shown in Fig. 3 are highlighted.

velocity structures beneath the surface. We therefore refer to the basement that lies beneath most of the modern forearc as the Piñón terrane (Baldock 1982). The Piñón terrane is also inferred offshore in the basement of the margin from 2-D and 3-D seismic refraction experiments, (Gailler et al. 2007; Garcia Cano et al. 2014). A large outcropping of the Piñón terrane (e.g. van Melle et al. 2008) lies in southern Ecuador and is bounded by the Jipijapa Fault (JPF) and is associated with the Chongón-Colonche Cordillera (CCC). The area associated with the $\mathrm{CCC}$ also has several outcroppings of the Cayo Formation and other mafic basement units. Coastward of the CCC lies the San Lorenzo block. All of the forearc units were accreted onto the South American margin between the late Paleocene and the Eocene (see Luzieux et al. 2006 and references therein). On top of the forearc basement blocks are several sedimentary packages with notable basins in the north and south, the Manabí (e.g. Jaillard et al. 1995) and Progreso (e.g. Moberly et al. 1982) basins, respectively (Fig. 1).

Preceding the accretion of the forearc terranes was the addition of island arc and plateau units that now lie in the Ecuadorian Cordillera, such as the Macuchi, Guaranda and Pallatanga blocks (e.g. Kerr \& Tarney 2005; Jaillard et al. 2009). These units are located adjacent to the modern active arc and have undergone varying degrees of deformation due to the rising of the Andes. The major faults and shear systems in the region are the Pallatanga fault system (PF) in the south, and the Pujili fault system (PJF) and the Chimbo-Toachi Shear Zone (CTSZ), which both roughly follow the emergence of Andean topography and bound accreted Cordilleran blocks (e.g. Jaillard et al. 2009; Nocquet et al. 2014; Alvarado et al. 2016).
The Ecuadorian convergent margin has produced several large recorded seismic events in the past century. In 1906, a $M_{\mathrm{w}} 8.5-8.8$ earthquake ruptured $\sim 500 \mathrm{~km}$ of the plate interface, stretching from southern Colombia to Ecuador (e.g. Kanamori \& McNally 1982). Multiple large $\left(M_{\mathrm{w}} \geq 7.7\right)$ events have subsequently occurred along that same segment (in 1942, 1958 and 1979; Kanamori \& McNally 1982; Beck \& Ruff 1984; Swenson \& Beck 1996) culminating in the recent $M_{\mathrm{w}} 7.816$ April 2016, Pedernales earthquake, which ruptured a similar segment to the 1942 earthquake (Ye et al. 2016; Nocquet et al. 2017). There appears to be segmentation in megathrust behaviour along the margin, with a southern boundary at $\sim 1^{\circ} \mathrm{S}$ as determined by aftershock studies for events prior to 2016 (Kanamori \& McNally 1982; Beck \& Ruff 1984; Swenson \& Beck 1996) and rupture patch modelling of the 2016 event (Nocquet et al. 2017). This hypothesized boundary has previously been attributed to the presence of the Carnegie Ridge acting as barrier to southward rupture (e.g. Collot et al. 2004; Gailler et al. 2007).

Along the Carnegie Ridge near La Plata island, significant slowslip seismic events (SSEs) occurred in 2010, 2013 and again in 2016 following the Pedernales event (Vallée et al. 2013; Rolandone et al. 2018; Segovia et al. 2018). There has also been a series of SSEs north of the Carnegie Ridge (e.g. Vaca et al. 2018) in the PuntaGalera-Mompiche-Zone (PGMZ) as well as deeper slow slip events farther inland both before and after the Pedernales earthquake (e.g. Rolandone et al. 2018). Several hundred kilometres south of the earthquake segment boundary, a $M_{\mathrm{w}} 7.5$ event occurred in 1953 at $\sim 3.5^{\circ} \mathrm{S}$ (International Seismological Centre 2016), but this event likely did not rupture much (if any) of the mega-thrust given its size and likely location in the upper plate (Fig. 1). 
Following the $M_{\mathrm{w}} 7.8,2016$ Pedernales earthquake there was a concerted effort to rapidly deploy seismic instruments along the Ecuadorian margin. Having a precise understanding of crustal velocity structure in the forearc and Andes will aid in better locating earthquakes of the aftershock sequence. An international deployment of seismic instruments was conducted for $\sim 1$ yr following the 2016 event (Meltzer et al. 2019). Combining data from the temporary international deployment with the permanent Ecuadorian national seismic network (RENSIG; Alvarado et al. 2018) and global seismic networks, we compile a data set that, when interrogated with a technique such as ambient noise tomography (ANT), can image forearc and Cordilleran shear velocity structure in great detail.

Ambient noise tomography takes advantage of surface wave energy generated from noise sources to examine shear velocity structure in the Earth (e.g. Bensen et al. 2008; Lin et al. 2008; Lynner et al. 2018). From noise-generated surface waves, we can extract phase velocity measurements for periods from 8- to 40-s between all contemporaneously operating seismic stations in Ecuador (e.g. Lynner and Porritt 2017). We then invert phase velocities for $\mathrm{V}_{\mathrm{sv}}$ across our study area. Here, we present ANT shear wave velocity results for the Ecuadorian forearc and Cordilleran regions. We see pronounced slow velocity anomalies associated with basins as well a body of fast velocity material that coincides with the Carnegie ridge and the southern extent of large mega-thrust earthquakes.

\section{DATA AND METHODS}

The international response to the Pedernales earthquake initially included five broad-band stations from the IG-EPN. A further 29 broad-band (120-s corner period) and 14 intermediate period (40$\mathrm{s}$ corner period) instruments were later deployed by international collaborators. In addition to the broad-band and intermediate period instruments used in this study, several short-period, strong-motion, ocean-bottom and GPS instruments were deployed as part of the international response (Meltzer et al. 2019).

We utilize data recorded at broad-band and intermediate period seismic stations to image variations in shear wave velocities in Ecuador via ambient noise tomography. We follow the processing methods of Bensen et al. (2008) to perform our analyses, which we summarize here. Vertical component day-long waveforms have their means removed, are detrended, tapered, corrected for station response, and whitened. A running-absolute-mean temporal normalization is then applied to each trace in order to remove earthquakegenerated energy. Seismograms are cross-correlated between all contemporaneously operation stations. Day-long cross-correlations are stacked to form empirical Green's functions (EGFs; Fig. S1) from which phase velocities are measured [Figs 2, S2, S3 and S4; see Bensen et al. (2008) for further details].

We extract phase velocities from the EGFs using traditional frequency-time analysis (FTAN; Levshin et al. 1992). We choose to use phase velocities instead of group velocities in our ANT inversions due to the robustness of their measurements in FTAN. We analyse periods between 8 -s and 40-s ensuring that we do not extend beyond the corner frequency of the intermediate period instruments. This data set includes phase velocity measurements from over 5800 interstation paths across 11 periods $(8,10,12,14,16,18$, $20,25,30,35$ and $40 \mathrm{~s}$ ) with peak coverage (773 paths) at a period of $16 \mathrm{~s}$ (Fig. S3). We retain only dispersion measurements from high signal-to-noise ratio ( $>3$ ) EGFs in our inversions. We exclude all measurements resulting from station pairs with interstation path lengths less than 2 wavelengths. This criterion allows us to avoid interference from overlapping surface wave energy with precursory arrivals and to satisfy the far-field approximation. Dispersion results from interstation distances as low as 1 wavelength have been shown to be reliable (Luo et al. 2015; Jiang et al. 2016), but we choose to use the 2-wavelength criterion in order to be confident in our phase velocity results (e.g. Lynner \& Porritt 2017). From the individual phase velocity measurements, we invert for regional phase velocity maps (Fig. S4) with a grid spacing of $0.1^{\circ}$ by $0.1^{\circ}$ (with constant alpha, beta, and gamma inversion parameters of 300, 150 and 150, respectively) following Barmin et al. (2001). Shear velocities are then inverted from our phase velocity maps on the same grid spacing (Herrmann 2013). We parametrize the shear velocity inversions using 2-km-thick layers in the upper $50 \mathrm{~km}, 5-\mathrm{km}$-thick layers in the subsequent $80 \mathrm{~km}$ and 10-km-thick layers below $130 \mathrm{~km}$. Finally, we correct for topography by shifting our shear velocity results given the topography calculated from the ETOPO model for each model cell (Amante and Eakin 2009).

To ensure that our inverted shear velocity model results are robust, we tested several different starting models: (1) a 'mantle-only' 1-D model with mantle velocities $\left(4.5 \mathrm{~km} \mathrm{~s}^{-1}\right)$ in the upper $50 \mathrm{~km}$ and AK135 (Kennett et al. 1995) velocities beneath $50 \mathrm{~km}$, (2) a 1-D model with crustal $\left(3.6 \mathrm{~km} \mathrm{~s}^{-1}\right)$ velocities in the upper $26 \mathrm{~km}$, mantle velocities $\left(4.5 \mathrm{~km} \mathrm{~s}^{-1}\right)$ to $50 \mathrm{~km}$, and AK135 velocities at deeper depths and (3) the a priori 3-D $V_{p}$ model from the study of Font et al. (2013) using a $V_{p} / V_{s}$ ratio of 1.78 (Fig. S5). We show inversion results produced using the $3-\mathrm{D}$ starting model from Font et al. (2013) for the remainder of this paper because the starting model is based upon observations and incorporates significant features we know are present in the region, such as the subducting slab. We use the simpler starting models as a check on the robustness of the results generated using the Font et al. (2013) model. We only discuss structures that are present in results derived from, and that alter, all three starting models since seismic features dictated by the data should be universally present.

Using an aftershock-focused seismic data set along the coast can be detrimental to ambient noise based studies due to the prevalence of significant earthquake-generated energy and a non-uniform distribution of noise sources. The bias created by noise sources predominantly coming from the coast has previously been shown to be quite small, impacting velocities by less than $\sim 0.6$ per cent (e.g. Compte et al. 2016). Since this is far less than the velocity perturbations we observe and interpret in this study, we consider this bias to be negligible. We address the potential signal contamination from earthquake-generated energy through the running-absolutemean temporal normalization (Bensen et al. 2008) applied to each seismogram. We throw out all daily traces that have had greater than 10 per cent of their recordings impacted by earthquake-generated noise. This approach leads to the removal of a significant amount of data from our cross-correlations when aftershock activity is high. On average, each station pair used in this study included $\sim 254 \mathrm{~d}$ of data. We have chosen to take this conservative approach in throwing out low-quality ANT data in order to be confident in attributing the energy that we do observe to noise-generated sources.

\section{RESULTS}

Shear velocity maps inverted from the 3-D starting model of Font et al. (2013) are shown in Fig. 3, and cross-sections through the model are shown in Fig. 4. Shear velocity maps and cross-sections for results using other starting models can be found in Figs S6, S7, 

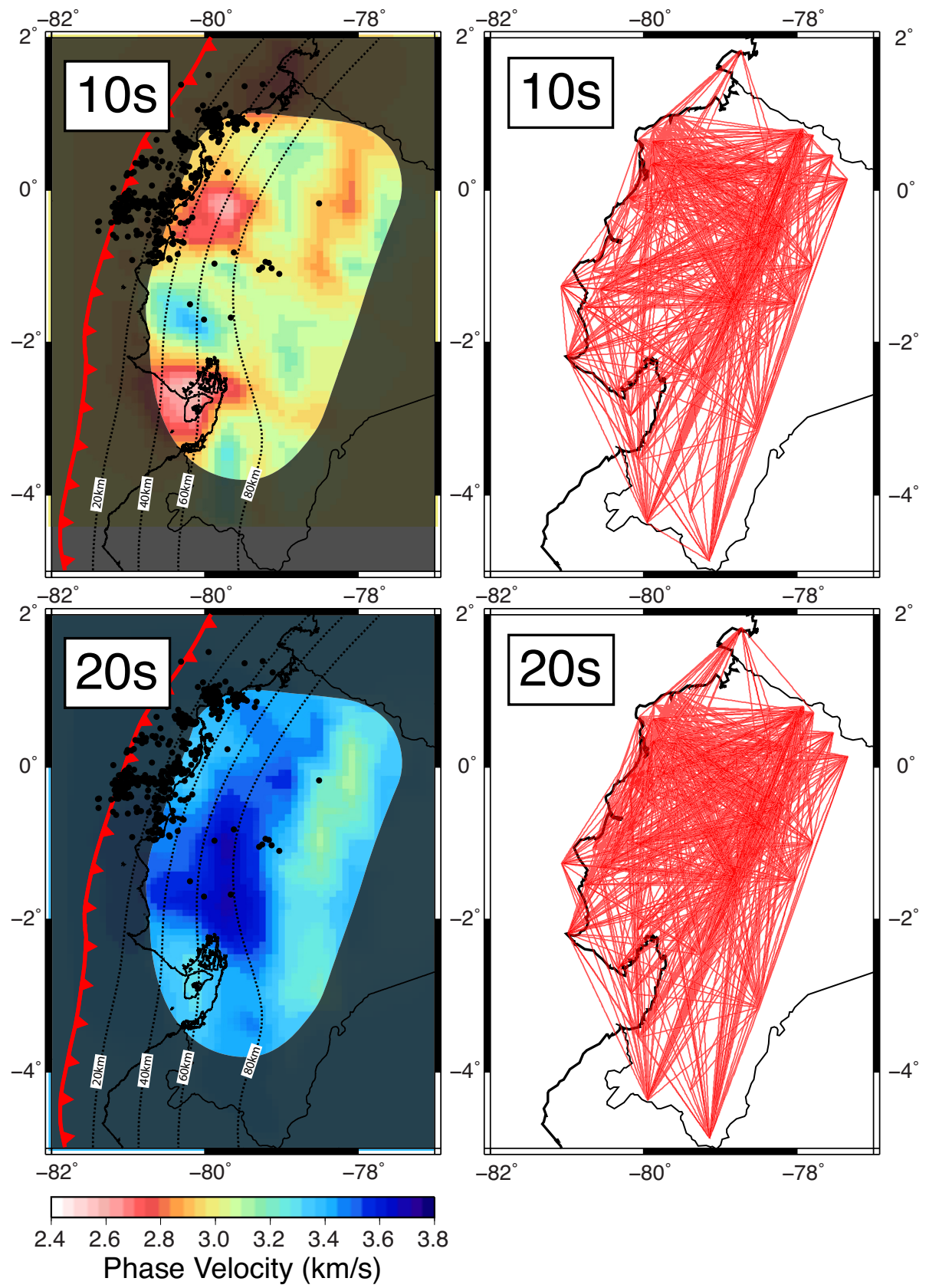

Figure 2. Phase velocity and ray coverage maps at 10 - and 20-s periods. Two slow velocity anomalies are apparent at 10 -s period and a fast velocity anomaly dominates at 20-s. We show slab contours from Slab2 (Hayes et al. 2018) and aftershock events as black circles (Meltzer et al. 2019). The shaded region highlights the area with sufficient ray coverage.

S8 and S9. There are two prominent slow velocity anomalies (less than $3 \mathrm{~km} \mathrm{~s}^{-1}$ ) present at $\sim 10 \mathrm{~km}$ depth, Fig. 3. Between the slow velocity anomalies lies a region of faster seismic velocities. This higher velocity material $\left(\sim 3.7 \mathrm{~km} \mathrm{~s}^{-1}\right)$ becomes more pronounced at $\sim 20 \mathrm{~km}$ depth $\left(\sim 4.2 \mathrm{~km} \mathrm{~s}^{-1}\right)$. Farther inland, higher seismic velocities $\left(\sim 4.0 \mathrm{~km} \mathrm{~s}^{-1}\right)$ are observed beneath the entirety of the forearc at $\sim 20 \mathrm{~km}$ depth. At $30 \mathrm{~km}$ and deeper, the boundary between the fast forearc $\left(\sim 4.3 \mathrm{~km} \mathrm{~s}^{-1}\right)$ and slow Andean $\left(\sim 3.6 \mathrm{~km} \mathrm{~s}^{-1} \mathrm{~s}\right)$ crustal region is striking. The fast forearc material contrasts sharply with the slower material of the Ecuadorian Andes. This transition is apparent in both the shear (Fig. 3) and phase (Figs 2 and S4) velocity maps. Since the depth structure of the Moho in Ecuador is not well constrained [e.g. Arujo 2013], we are unable to say if the lateral velocity change is related to crustal velocity variations or due to a transition between mantle material in the forearc and the crustal root of the Andes.

Our models are well resolved in the region highlighted in Fig. 3 (see Figs S10, S11 and S12). We have good depth sensitivity between the shallow crust (below $\sim 5 \mathrm{~km}$ ) and depths of $\sim 40 \mathrm{~km}$ with decreasing resolution to $\sim 50 \mathrm{~km}$ depth. Laterally resolvable features in our ANT models are on the order of $\sim 75-100 \mathrm{~km}$ depending on ray path density and period. Our models have peak sensitivity between $\sim 10$ and $\sim 30 \mathrm{~km}$ depth. Lateral resolution degrades to $\sim 100-125 \mathrm{~km}$ at longer periods (those corresponding to depths 

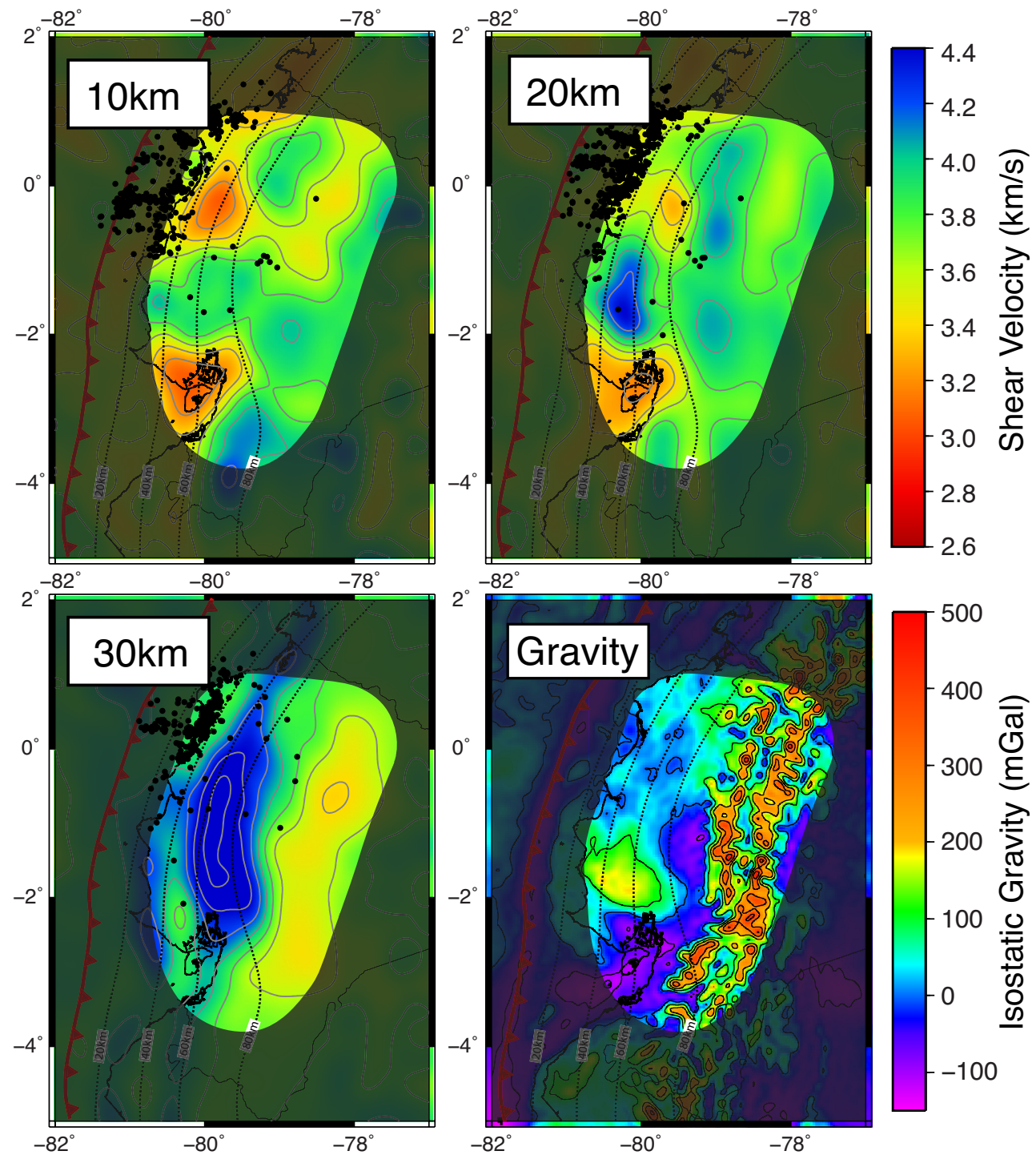

Figure 3. Shear velocity maps at 10, 20 and $30 \mathrm{~km}$ depth inverted from phase velocities using the starting model of Font et al. (2013). Slab contours from Slab2 (Hayes et al. 2018) are the same as shown as in Fig. 1. We also present isostatic gravitational anomalies across Ecuador (Bonvalot et al. 2012). Aftershock events are shown as black circles (Meltzer et al. 2019).

between 30 and $50 \mathrm{~km}$; Figs S10 and S11). We have rapidly diminishing sensitivity to structures in the upper $\sim 5 \mathrm{~km}$ of our model due to Rayleigh wave sensitivities decreasing towards the surface at the periods measured in this study (Fig. S12). While there is some streaking in our models, it is generally orthogonal to the anomalies we interpret (Figs S10 and S11). Our final model also does a good job of reducing misfits between the dispersion measurements and a homogeneous model (Figs S13 and S14).

In addition to traditional checkerboard resolution tests, we also performed a bootstrap analysis on our tomographic inversions. This allows us to evaluate which regions of our model are the most robust. We randomly resampled with replacement our interstation phase velocity measurements ensuring equal sized data sets. We then re-inverted for phase velocity maps and shear velocities 100 times following the steps described above. The standard deviation of our shear velocity models calculated from the bootstrap runs can be seen in Fig. 5. Our shear velocity models are remarkably well behaved, with an average standard deviation of less than $\sim 0.2 \mathrm{~km} \mathrm{~s}^{-1}$ and a peak standard deviation of $\sim 0.5 \mathrm{~km} \mathrm{~s}^{-1}$ in a very restricted region.

Our interpreted results are further bolstered by the use of multiple starting models. We only discuss velocity features that emerge from all three starting models, such as the fast forearc velocities at $\sim 20 \mathrm{~km}$ depth and the distinct velocity change from the fast forearc to the slow Cordillera. There are several features that only appear in models derived from a single starting model that are likely tied to the initial input, such as the slab in cross-section $\mathrm{C}-\mathrm{C}^{\prime}$ in Fig. 4 that is likely a remnant of the Font et al. (2013) starting model. We have chosen not to interpret structures that are not seen across all of our models, as they may be dependent upon the starting model. Such features are not necessarily incorrect or artefacts (there is certainly a slab present), but we have chosen to take the conservative approach and focus only on the common data-driven velocity anomalies in the forearc. 

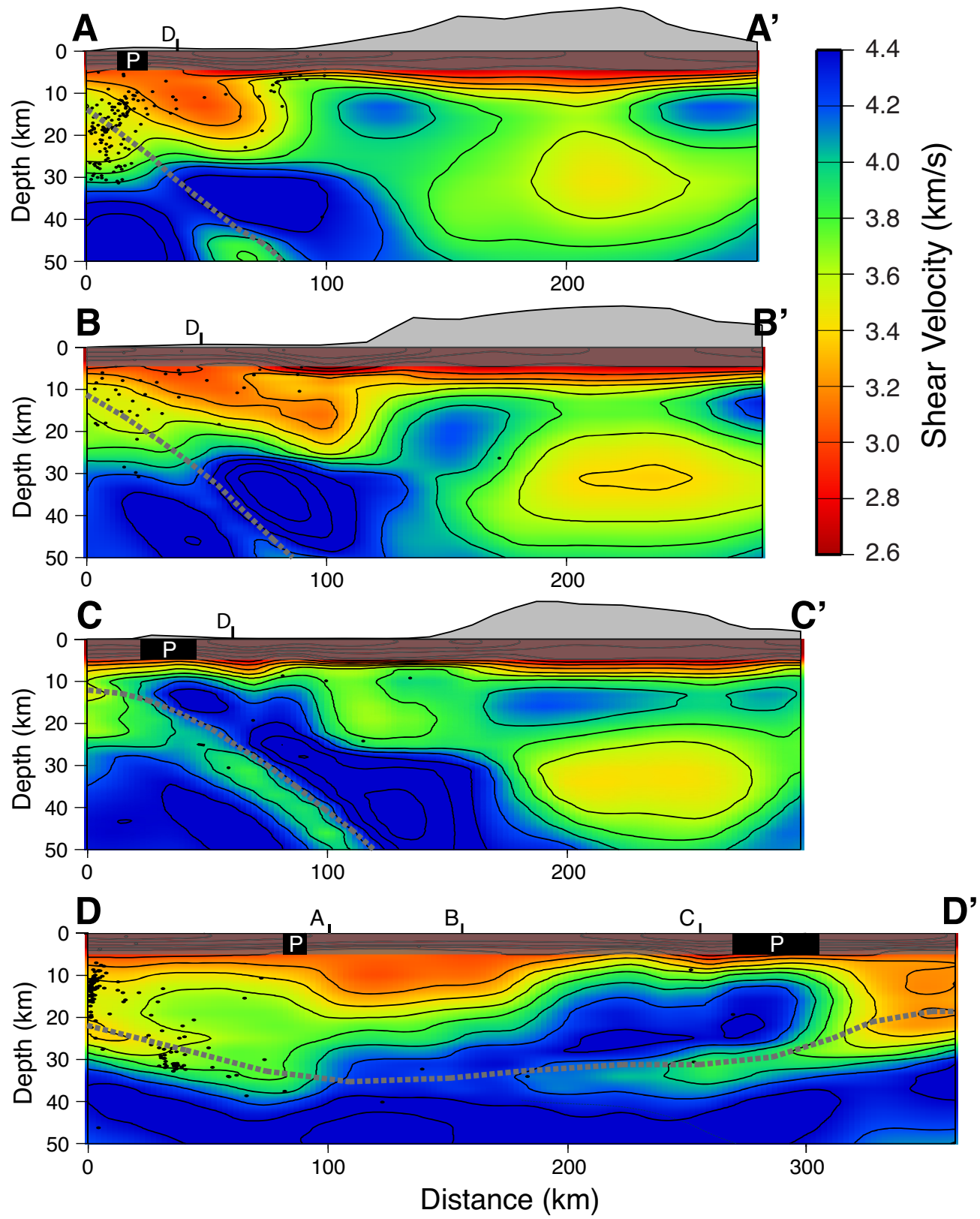

Figure 4. Cross-sections through our shear velocity model as shown in Fig. 1. The upper $5 \mathrm{~km}$ are obscured to reflect the depth sensitivity of our results. Black bars at the top denote outcrops of the Piñon terrane. Cross-section $\mathrm{A}-\mathrm{A}^{\prime}$ runs along $0^{\circ} \mathrm{N}$ and transects the rupture area of the Pedernales earthquake. Cross-section $\mathrm{B}-\mathrm{B}^{\prime}$ runs along $0.5^{\circ} \mathrm{S}$ and transects the Manabí Basin. Cross-section $\mathrm{C}-\mathrm{C}^{\prime}$ parallels $1.5^{\circ} \mathrm{S}$ and samples the FFA. The D- $\mathrm{D}^{\prime}$ cross-section highlights the Ecuadorian forearc. It traverses the Manabí basin in the north and the FFA in the south. Intersections with other cross sections are marked at top of each segement. Aftershock events within $10 \mathrm{~km}$ of each cross-section are shown as circles (Meltzer et al. 2019). The grey dashed lines denote the location of slab in the Font et al. (2013) starting model. The slower velocities of the subducting slab seen in cross-section C- $\mathrm{C}^{\prime}$ are likely a remnant of the starting model.

\section{DISCUSSION}

\section{Tectonic features}

The agreement between our tomographic models and known geologic features in Ecuador suggests our inverted results are robust. At depths greater than $\sim 30 \mathrm{~km}$, our ANT results closely match the extent of the high elevation Andes. The fast velocities in the forearc represent what we are calling the Piñón terrane. Fast seismic velocities are also seen farther offshore in the upper plate and may be also be related to the Piñón terrane (Gailler et al. 2007; Garcia Cano et al. 2014). Our ANT results, however, do not extend offshore making linking the offshore and forearc fast velocities difficult. This fast unit underlies the majority of the forearc and is seen at depths below $\sim 20 \mathrm{~km}$. The boundary between the fast forearc accreted material and the slow crustal material of the Andes closely follows the CPFZ and CTSZ, and therefore the Pallatanga block as shown in Fig. 6. The location of the velocity change suggests the Pallatanga block represents the boundary between the forearc and the Cordillera (Fig. 7). Due to the unknown nature of fault structures at depth, and the lateral resolution of our ANT models $(75-100 \mathrm{~km})$, the boundary between fast and slow velocity material may represent the demarcation between original South American Plate material 

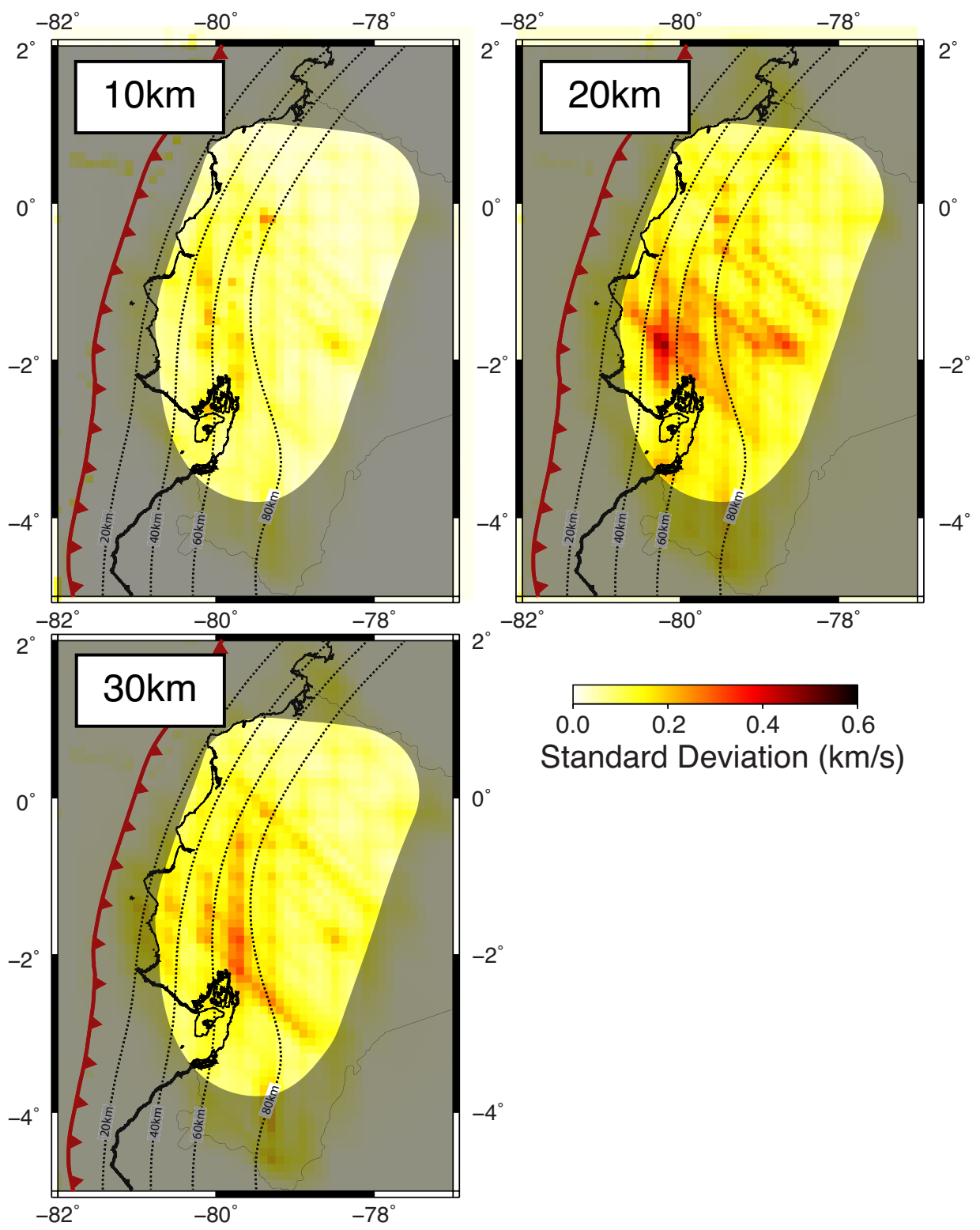

Figure 5. Maps of standard deviation in our shear velocity model based on the bootstrap resampling of our ANT results. The vast majority of our model does not vary more than $\sim 0.2 \mathrm{~km} \mathrm{~s}^{-1}$, with a very localized region of maximum variance of $0.53 \mathrm{~km} \mathrm{~s}^{-1}$.

and forearc accretionary blocks, or it may simply highlight the transition between deep Andean crustal material, such as the Pallatanga block and/or the easternmost portion of the Macuchi Island arc, and the relatively undeformed accreted units in the forearc. In either case, the deep, slow Andean root is easily distinguished from fast forearc velocities.

We have little resolution in the shallowest $\sim 5 \mathrm{~km}$ of our models making imaging basins challenging. At shallow (5-10 km) depths, however, our models highlight very slow $\left(<3.0 \mathrm{~km} \mathrm{~s}^{-1}\right)$ velocity anomalies that correlate well with very deep portions of the Manabí and Progreso basins to the north and south, respectively. In the north, the Manabí basin lies in a region that is laterally well resolved by our data and correlates with the coseismic rupture of the Pedernales earthquake. While the depth sensitivity of our models limits the ability to image the entire basin, our results suggest that the northern Manabí basin is in places quite deep (maybe up to $\sim 10 \mathrm{~km}$ ). The depth of the Manabí basin is poorly constrained in the literature, making this one of the few estimates of the basin. We note, however, that ANT studies have a tendency to bias results to greater depths in the upper $\sim 10 \mathrm{~km}$ due to the diminishing sensitivity of Rayleigh waves towards the surface (Fig. S12). The depth of the Manabí basin may be shallower than we image here.

In the southern portion of our model, where the Progreso basin is located, there is the potential issue of signal contamination from the oceanic basin. Previous studies have shown, however, that transcoast ANT still produces reliable shear velocity structures (e.g. Porritt et al. 2016). Since our results closely match the location of the Progreso basin, we are confident that we are imaging such a feature. While this slow anomaly associated with the Progreso basin is robust, it lies in a region of relatively low resolution (Figs 5, S3, S10 and S11). The uncertain structure of the basins beneath the surface (e.g. areal and depth extents) likely accounts for the differences between the basin surface expressions and the sizes of the velocity anomalies. 

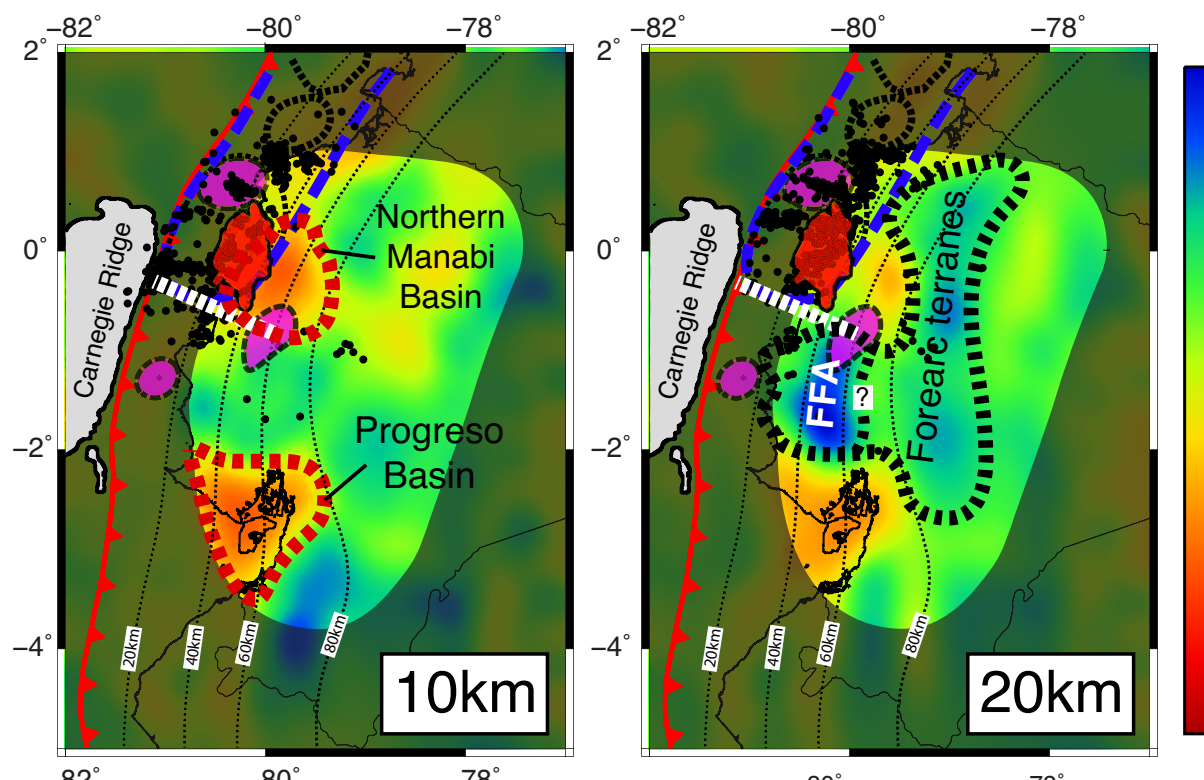

4.4

4.2
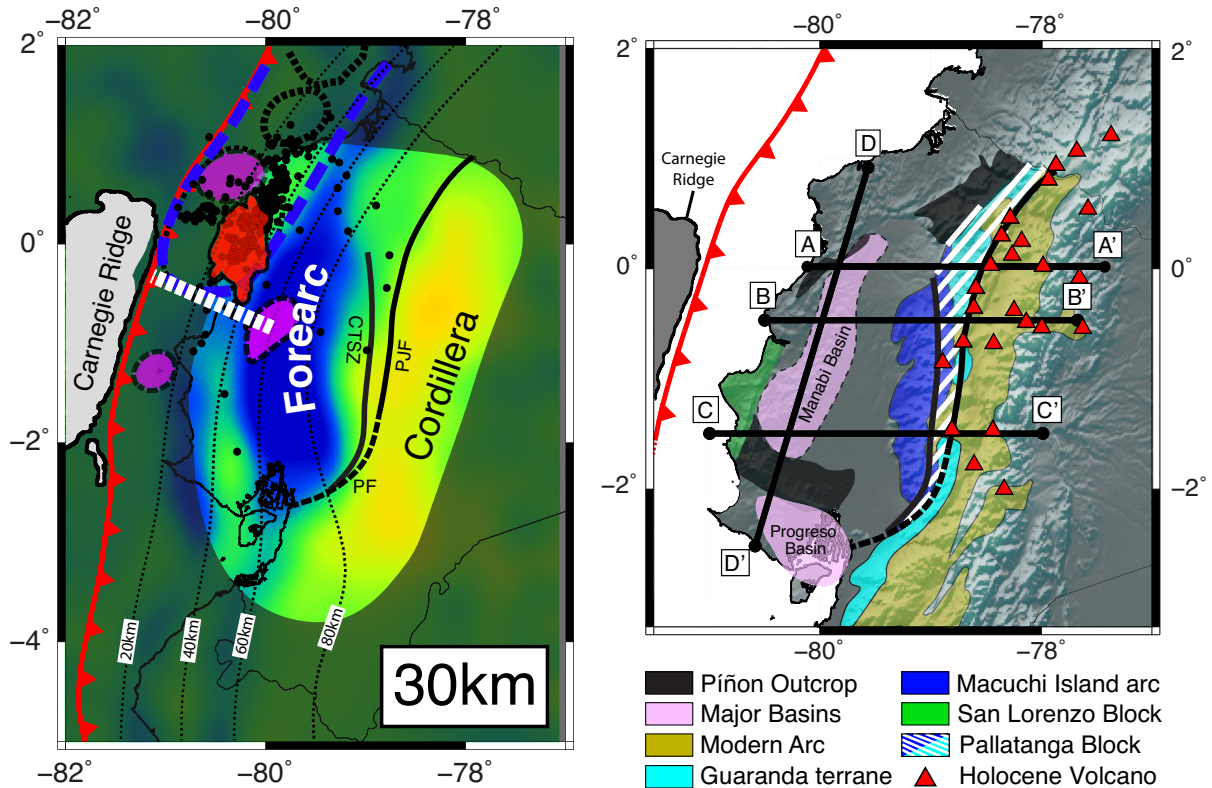

Figure 6. Interpretive schematic plotted on top of our shear velocity maps. The deepest parts of the Manabí and Progreso basins are present in the shallowest depth map at $10 \mathrm{~km}$. At $20 \mathrm{~km}$ depth, the slow velocities related to sedimentary basins disappear and the FFA emerges. While not as fast $\left(>3.5 \mathrm{~km} \mathrm{~s}^{-1}\right)$ as the FFA, elevated shear velocities are also observed throughout the forearc. Below $30 \mathrm{~km}$, the fast velocity forearc material is easily distinguished from the slow material of the high elevation Andes. This transition closely corresponds to the CPFZ, CTSZ and the Pallatanga block as shown in Fig. 1. Our suggested large event segment boundary is highlighted as the white dashed line just south of the approximate aftershock area of the 1906 event (dashed blue ellipse), the simplified aftershock areas of other large $\left(M_{\mathrm{w}} \geq 7.7\right)$ mega-thrust events (dashed black ellipses; Kanamori \& McNally 1982; Beck \& Ruff 1984; Swenson \& Beck 1996), and the high slip region determined for the 2016, Pedernales earthquake (red patch; Nocquet et al. 2017).

A slow $\left(\sim 3.7 \mathrm{~km} \mathrm{~s}^{-1}\right)$ velocity anomaly that extends to $\sim 20$ $25 \mathrm{~km}$ depth (Figs 6 and 7) is present beneath the Manabí basin. There is little-to-no surface expression of this slower material making it difficult to assess its affinity. This deeper anomaly correlates with the co-seismic rupture of the 2016 Pedernales earthquake and appears linked to deeper aftershock events. Fig. 4 shows a crosssection $\left(\mathrm{D}-\mathrm{D}^{\prime}\right)$ through this slow anomaly along with aftershock locations measured in the year following the 2016 earthquake (Meltzer et al. 2019). While the Manabí basin is present at depths less than $\sim 10 \mathrm{~km}$, the deeper, slow velocity anomaly seems to contain several deep aftershocks, while the faster $\left(>4.0 \mathrm{~km} \mathrm{~s}^{-1}\right)$ material is lacking similar deep aftershocks (Fig. 7). The relative difference in aftershock behaviour may indicate that the slow velocity region behaves differently than the faster velocity material that surrounds it.

This relatively slower $\left(\sim 3.7 \mathrm{~km} \mathrm{~s}^{-1}\right.$ versus $\left.\sim 4.1 \mathrm{~km} \mathrm{~s}^{-1}\right)$ forearc

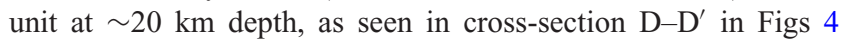
and 7, is likely associated with either: (1) altered crustal material (via the presence of fluids), (2) an altered accreted terrane that exhibited thick oceanic crustal material, such as an oceanic plateau or (3) a serpentinized unit that was accreted into the forearc. As the Ecuadorian forearc lies above a mainly erosional subduction system (Collot et al. 2002), the downgoing slab is likely releasing fluids as it heats up and descends into the mantle. These rising subduction fluids have the potential to alter the material above it producing 

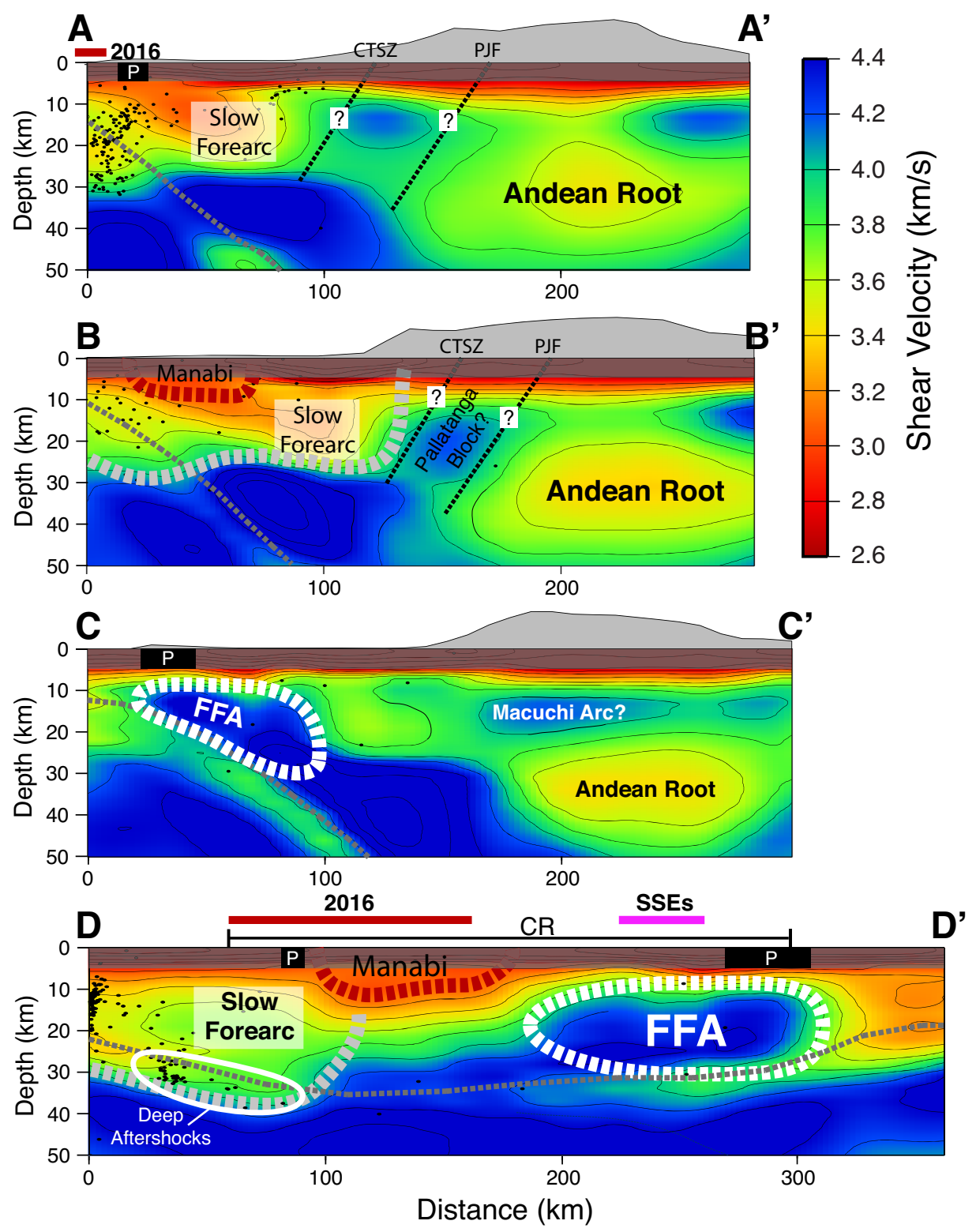

Figure 7. Schematic interpretation plotted on top of the cross-sections shown in Fig. 4. We highlight the deepest portions of the Manabí basin in cross-sections B-B' and D-D'. A deeper slow velocity anomaly emerges beneath the Manabí basin that correlates with the co-seismic rupture of the Pedernales earthquake. Deep aftershock events associated with this slow anomaly are highlighted in cross-section D- $\mathrm{D}^{\prime}$. In cross-sections $\mathrm{C}-\mathrm{C}^{\prime}$ and $\mathrm{D}-\mathrm{D}^{\prime}$, the FFA is striking. In the northern transects $\left(\mathrm{A}-\mathrm{A}^{\prime}, \mathrm{B}-\mathrm{B}^{\prime}\right)$ the boundary between fast forearc and slow Andean material closely matches the CTSZ, CPFZ and the Pallatanga Block. The lateral extent of the 2016 Pedernales rupture (Nocquet et al. 2017), SSEs (Vallée et al. 2013; Rolandone et al. 2018; Segovia et al. 2018; Vaca et al. 2018) and

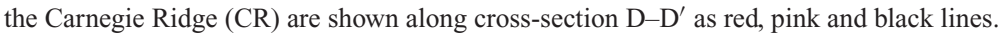

slow seismic velocities (e.g. Peacock 1993; Bostock et al. 2002; Hyndman \& Peacock 2003). If the slow anomaly extends to the plate interface, as it appears in our models, it may be the endproduct of slab dehydration. While there is no surface evidence of such dehydration beneath the Manabí basin, farther east beneath the Andes such a mechanism has been suggested (Hidalgo et al. 2007).

Alternatively, the slow $\left(\sim 3.7 \mathrm{~km} \mathrm{~s}^{-1}\right)$ velocity anomaly may reflect the accretion of material with those velocities into the forearc. The Ecuadorian margin is comprised of many accreted terranes. The accretion, and subsequent alteration, of an overthickened oceanic plateau with relatively slow seismic velocities (e.g. velocities slightly slower than the Shatsky Rise $\sim 3.8-3.9 \mathrm{~km} \mathrm{~s}^{-1}$; Korenaga $\&$ Sager 2012) could account for the anomaly if the accreted block were altered to produce slower velocities $\left(V S\right.$ of $\left.\sim 3.7 \mathrm{~km} \mathrm{~s}^{-1}\right)$. Similarly, the addition of a serpentinized sliver into the forearc would result in a slow velocity unit (Ji et al. 2013). This scenario has been suggested in other forearc settings (e.g. Nikulin et al. 2009; Shao et al. 2014; Krueger \& Wirth 2017) and may be a reasonable mechanism for the Ecuadorian forearc.

All three explanations can extend to the bottom of the upper-plate. Each mechanism has the potential to alter the frictional properties of the slab-interface by weakening the upper-plate. This may be consistent with what we see in the distribution of aftershocks in the region, where events extend down to the bottom of the slow velocity anomaly (Fig. 4). If the material is weaker or has been altered by fluids, it may be more prone to seismic events than the surrounding 
stronger/unaltered regions surrounding it by slipping more easily along fractures and faults. This area warrants further study to discriminate between the different scenarios described above and their possible relationships to the Pedernales earthquake rupture, subsequent aftershock sequence, and future hazard. The slow velocity anomaly may extend down to the plate interface and may play an important role in the behaviour of the mega-thrust.

Separating the Manabí and Progreso basins is a region of fast $\left(\sim 4.3-4.4 \mathrm{~km} \mathrm{~s}^{-1}\right)$ shear velocities that is readily apparent at $\sim 20 \mathrm{~km}$ depth (Figs 3 and 6). The fast forearc anomaly (FFA) emerges regardless of chosen starting model (Figs 3, S6 and S7). The fact that this structure emerges despite very simple homogenous starting models as well as the more complex 3-D starting model of Font et al. (2013) suggests it is a robust feature. It also coincides with the southern extent of large $\left(M_{\mathrm{w}} \geq 7.7\right)$ mega-thrust earthquakes in the region, with a significant gravitational anomaly, and with the southern portion of the subducting Carnegie Ridge (Fig. 3). This represents the first time the FFA has been imaged seismically and combined with the associated gravity anomaly, it is likely a distinct body within the Ecuadorian forearc.

The FFA has many possible affinities including the subduction of the Grijalva rifted margin (Yepes et al. 2016), large outcropping of the Piñón terrane, the Chongón-Colonche Cordillera, and/or the San Lorenzo Block (Fig. 1). It may also represent a buried accreted body that has no surface expression. It is unlikely that the FFA is the result of downgoing Carnegie Ridge material being accreted into the upper plate. The FFA exhibits seismic velocities $\left(\sim 4.3-4.4 \mathrm{~km} \mathrm{~s}^{-1}\right)$ that are much faster than typical oceanic crust $\left(\sim 3.8-4.0 \mathrm{~km} \mathrm{~s}^{-1}\right)$ and are more consistent with a mafic mantle source (e.g. Lynner et al. 2018) despite currently being at crustal depths. The FFA also extends several kilometres into the overriding plate and appears to have slower material beneath it (Figs 4 and 7). The FFA also does not seem to extend to the coast suggesting it is a restricted body. We argue that the FFA is an accreted unit that carried with it lithospheric mantle material. During its incorporation into the upper plate, the FFA either lost crustal material or more likely had very little crust to begin with. This supports the notion that the FFA has an oceanic affinity like the majority of the accreted bodies in the forearc. While the FFA seems to be a distinct unit with seismic and gravity properties that are different than the surrounding material, we cannot fully rule out that it is accreted Carnegie Ridge material.

\section{Forearc structure and mega-thrust earthquake behaviour}

The Ecuadorian convergent margin has produced several large recorded seismic events in the past century. In 1906, a $M_{\mathrm{w}} 8.5-$ 8.8 earthquake ruptured $\sim 500 \mathrm{~km}$ of the plate interface followed by events in 1942, 1958 and 1979 that together ruptured the same segment as the 1906 event (e.g. Kanamori \& McNally 1982; Beck \& Ruff 1984; Swenson \& Beck 1996). More recently, the $M_{\mathrm{W}} 7.8$ 16 April 2016, Pedernales earthquake ruptured a similar segment to the 1942 earthquake (Ye et al. 2016; Nocquet et al. 2017). There appears to be variation in the segmentation in mega-thrust behaviour along the margin with a possible rupture barrier at $\sim 1^{\circ} \mathrm{S}$. This hypothesized boundary has previously been attributed to the presence of the subducting Carnegie Ridge acting as barrier to southward rupture (e.g. Collot et al. 2004; Gailler et al. 2007). South of the Carnegie Ridge between $\sim 1^{\circ} \mathrm{S}$ and $\sim 4^{\circ} \mathrm{S}$, the historic earthquake record is less well known but there have been no recorded $M_{\mathrm{w}} \geq 7.7$ events.
The FFA coincides with the southern portion of the subducting Carnegie Ridge and the event segmentation boundary. Given the stark difference in velocity and gravity properties of the FFA relative to the surrounding upper-plate material, it (in addition to the Carnegie Ridge) may play an important role in the development of an earthquake rupture segment boundary. The fast velocities and elevated gravity of the FFA suggests it has a mantle source and may be stronger than its surrounding forearc material. Having an isolated strong region in the forearc could be the cause of the event segmentation along the margin due to the weak surrounding material yielding first. This raises the possibility that a sufficiently large seismic event could rupture across the FFA and the segment boundary, although such an event has not been observed. From the velocities and gravity alone, however, we have few constraints on the actual characteristics of the FFA. Additionally, if the FFA has frictional properties at depth that are non-conducive to large events, such as having properties that promote aseismic slip, its accretion onto the Ecuadorian margin represents a possible barrier to propagation of very large earthquakes and may also account for the SSEs that occurred along the margin (Vallée et al. 2013; Rolandone et al. 2018; Segovia et al. 2018).

The eastward (and also depth) extent of the FFA (Figs 6 and 7) may further play a role in its impact on mega-thrust behaviour. The fast velocities associated with the FFA extend farther east and slightly deeper than where mega-thrust events tend to nucleate and propagate. This is apparent in Figs 6 and 7, where the fast anomaly corresponds to an area of the upper plate that appears to be in contact with the slab interface at depths to $\sim 40 \mathrm{~km}$. We note, however, that it is difficult to establish the exact depth extent of the FFA from our models given the $\sim 5 \mathrm{~km}$ depth sensitivity provided by our imaging. From analyses of aftershock patches of large events prior to 2016 (Kanamori \& McNally 1982; Beck \& Ruff 1984; Swenson \& Beck 1996) and the depth extent of the 2016 Pedernales earthquake rupture (Collot et al. 2017), large $\left(M_{\mathrm{w}} \geq 7.7\right)$ events in this area tend to not propagate to depths greater than $\sim 30-40 \mathrm{~km}$ (Fig. 1). Since the FFA seems to extend to, or past, this depth (Fig. 6), it could potentially impact the plate interface throughout the mega-thrust rupture region.

The subducting Carnegie Ridge and the location of the FFA appears to present a mega-thrust segment boundary since we have yet to see an event rupture completely across it. Recent interplate coupling models suggest relatively strong coupling north of the Carnegie Ridge where the 1906, 1942 and 2016 earthquakes occurred (Chlieh et al. 2014; Nocquet et al. 2014). In addition to the northern coupling, there is a small patch of strongly coupled plate interface southward of our proposed segment boundary that corresponds with the central portion of the subducting Carnegie Ridge in the La Plata area (Chlieh et al. 2014; Nocquet et al. 2014). It is possible that this smaller coupled region is able to support larger events, and we have just not yet observed the phenomenon. The small extent of this highly coupled region, however, would likely limit the size of a mega-thrust event. The southern event segment boundary as well as the role of the upper plate versus the downgoing plate in mega-thrust behaviour remains the focus of future research.

We suggest that the variable seismic properties of the upper plate along strike, that we have imaged here for the first time spanning from the FFA in the south to the weaker and/or altered material in the north, may play an important, previously unacknowledged, role in mega-thrust behaviour along Ecuadorian margin. While the role of the subducting Carnegie Ridge in the overall behaviour of the Ecuadorian mega-thrust is quite important, we suggest that the properties of the FFA, either as a strong block or with frictional 
characteristics that inhibit large events, may also help control the initiation and propagation of large subduction zone earthquakes. This calls for further studies of the properties of the FFA to discern its relative role in inhibiting or encouraging large mega-thrust events.

\section{CONCLUSION}

We present shear velocity models across the Ecuadorian forearc and Andes from ambient noise tomography. We observe several features that roughly correlate to observed surface geologic structures. At shallow depths, we see the deepest portions of the Manabí and Progreso basins as distinct slow velocity bodies separated by a region of fast velocity material. The fast anomaly separating the basins is apparent irrespective of starting model (Figs 3, S6 and S7) making it a robust observation. The fast region seems to directly correlate to the segmentation of plate boundary events where the Carnegie Ridge is subducting beneath Ecuador. Deeper than $30 \mathrm{~km}$, the fast forearc is evidently separated from the slower velocities of the active arc in the Cordillera. While fault structure at depth is unknown, our results suggest that the Chimbo-Toachi Shear Zone (CTSZ) and the Calacalí-Pujilí Fault Zone (CPFZ), and the corresponding Pallatanga Block, represent the boundary between the accreted fast forearc material and the slower, deeper Andean crust.

We suggest that the upper-plate in the Ecuadorian forearc may play a previously unacknowledged role in mega-thrust earthquake behaviour along the convergent margin. The location of the FFA matches the southern extent of the 1906 mega-thrust event as well as the southernmost extent of subsequent large earthquakes. This boundary also corresponds to the subduction of the Carnegie Ridge on the downgoing Nazca plate. From our ANT results alone it is impossible to differentiate the role of upper- and downgoing plate structure relative to the behaviour of mega-thrust events. This warrants further study in both Ecuador and in convergent margins worldwide.

\section{ACKNOWLEDGEMENTS}

We made figures using the Generic Mapping Tools developed by Wessel and Smith (1999). Publically available seismic data [networks 8G (Meltzer and Beck 2016), EC (Alvarado et al. 2018), and G (IGEP and EOST 1982)] were accessed via the Data Management Center of the Incorporated Research Institutions for Seismology. We also use data from the XE seismic network (Regnier et al. 2016). We thank the staff at the Instituto Geofísico at the Escuela Politécnica Nacional (IG-EPN) in Quito, Ecuador. We also thank all the field crews that helped in data collection. This work was supported by NSF EAR-1723065, NSF RAPID Program Award EAR-1642498 and by ANR project ANR-15-CE04-0004 and UCA/JEDI project ANR-15-IDEX-01. We also thank 2 anonymous reviewers for their useful comments.

\section{REFERENCES}

Alvarado, A. et al. 2016. Partitioning of oblique convergence in the Northern Andes subduction zone: migration history and the present-day boundary of the North Andean Sliver in Ecuador, Tectonics, 35(5), 1048-1065.

Alvarado, A. et al., 2018. Seismic, volcanic, and geodetic networks in Ecuador: building capacity for monitoring and research, Seismol. Res. Lett., 89(2A), 432-439.
Amante, C. \& Eakins, B.W., 2009. ETOPO1 1 arc-minute global relief model: procedures, data sources and analysis. NOAA Technical Memorandum NESDIS NGDC-24, National Geophysical Data Center, NOAA, doi:10.7289/V5C8276M

Araujo, S., 2013. The Ecuadorian moho, La Granja: Revista de Ciencias de la Vida, 18(2), 43-47.

Baldock, M.W., 1982. Geology of Ecuador. Explanatory Bulletin of the national geological map of the Republic of Ecuador, scale 1: 1,000,000 Direccion General de Geologia y Minas, Quito, Ecuador, 11, p. 54.

Barmin, M.P., Ritzwoller, M.H. \& Levshin, A.L., 2001. A fast and reliable method for surface wave tomography, in Monitoring the Comprehensive Nuclear-Test-Ban Treaty: Surface Waves, pp. 1351-1375, Birkhäuser, doi: 10.1007/978-3-0348-8264-4_3.

Beck, S.L. \& Ruff, L.J., 1984. The rupture process of the great 1979 Colombia earthquake: evidence for the asperity model, J. geophys. Res., 89 , 9281-9291.

Bensen, G.D., Ritzwoller, M.H. \& Shapiro, N.M., 2008. Broadband ambient noise surface wave tomography across the United States, J. geophys. Res, 113(B5), doi: 10.1029/2007JB005248.

Bonvalot, S. et al., 2012. World Gravity Map. Commission for the Geological Map of the World. Eds. BGI-CGMW-CNES-IRD, Paris.

Bostock, M.G., Hyndman, R.D., Rondenay, S. \& Peacock, S.M., 2002. An inverted continental Moho and serpentinization of the forearc mantle, Nature, 417(6888), 536.

Chlieh, M. et al., 2014. Distribution of discrete seismic asperities and aseismic slip along the Ecuadorian megathrust, Earth Planet. Sci. Lett., 400, 292-301.

Collot, J.Y., Charvis, P., Gutscher, M.A. \& Operto, S., 2002. Exploring the Ecuador-Colombia active margin and interplate seismogenic zone, EOS, Trans. Am. Geophys.Un., 83(17), 185-190.

Collot, J.Y. et al., 2017. Subducted oceanic relief locks the shallow megathrust in central Ecuador, J. Geophys. Res., 122(5), 3286-3305.

Collot, J.Y. et al., 2004. Are rupture zone limits of great subduction earthquakes controlled by upper plate structures? Evidence from multichannel seismic reflection data acquired across the northern Ecuador-southwest Colombia margin, J. geophys. Res., 109, 1-14.

Comte, D., Carrizo, D., Roecker, S., Ortega-Culaciati, F. \& Peyrat, S., 2016. Three-dimensional elastic wave speeds in the northern Chile subduction zone: variations in hydration in the supraslab mantle, Mon. Not. R. astr. Soc., 207(2), 1080-1105.

Font, Y., Segovia, M., Vaca, S. \& Theunissen, T., 2013. Seismicity patterns along the Ecuadorian subduction zone: new constraints from earthquake location in a 3-D a priori velocity model, Geophys. J. Int., 193(1), 263286.

Gailler, A., Charvis, P. \& Flueh, E.R., 2007. Segmentation of the Nazca and South American plates along the Ecuador subduction zone from wide angle seismic profiles, Earth planet. Sci. Lett., 260, 444-464.

García Cano, L.C., Galve, A., Charvis, P. \& Marcaillou, B., 2014. Threedimensional velocity structure of the outer fore arc of the colombiaecuador subduction zone and implications for the 1958 megathrust earthquake rupture zone, J. geophys. Res., 119, 1041-1060.

Hayes, G.P., Moore, G.L., Portner, D.E., Hearne, M., Flamme, H., Furtney, M. \& Smoczyk, G.M., 2018. Slab2, a comprehensive subduction zone geometry model, Science, 362(6410), 58-61.

Herrmann, R.B., 2013. Computer programs in seismology: an evolving tool for instruction and research, Seismol. Res. Lett., 84, 1081-1088.

Hidalgo, S., Monzier, M., Martin, H., Chazot, G., Eissen, J.P. \& Cotten, J., 2007. Adakitic magmas in the Ecuadorian volcanic front: petrogenesis of the Iliniza volcanic complex (Ecuador), J. Volc. Geother. Res., 159(4), 366-392.

Hyndman, R.D. \& Peacock, S.M., 2003. Serpentinization of the forearc mantle, Earth planet. Sci. Lett., 212(3-4), 417-432.

International Seismological Centre, 2016. On-line Bulletin, http://www.isc. ac.uk, Internatl. Seismol. Cent., Thatcham, United Kingdom.

IPGP (Institut De Physique Du Globe De Paris) and EOST (Ecole Et Observatoire Des Sciences De La Terre De Strasbourg), 1982. GEOSCOPE, French Global Network of broad band seismic stations. Institut 
de Physique du Globe de Paris (IPGP). Other/Seismic Network. doi: 10.18715/geoscope.g.

Jaillard, E., Lapierre, H., Ordonez, M., Alava, J.T., Amortegui, A. \& Vanmelle, J., 2009. Accreted oceanic terranes in Ecuador: southern edge of the Caribbean Plate?, Geol. Soc., Lond., Spec. Publ., 328(1), 469-485.

Jaillard, E., Ordonez, M., Suarez, J., Toro, J., Iza, D. \& Lugo, W., 2004. Stratigraphy of the late Cretaceous-Paleogene deposits of the Cordillera Occidental of central Ecuador: geodynamic implications, J. South Am. Earth Sci., 17(1), 49-58.

Jaillard, E., Ordoñez, M., Benitez, S., Berrones, G., Jiménez, N., Montenegro, G. \& Zambrano, I., 1995. Basin development in an accretionary, oceanic-floored fore-arc setting: southern coastal Ecuador during Late Cretaceous-Late Eocene time, in Petroleum Basins of South America, Vol. 62,pp. 615-631, eds Tankard, A.J., Suárez Soruco, R. \& Welsink, H.J., American Association of Petroleum Geologists Memoir.

Jiang, C., Yang, Y., Rawlinson, N. \& Griffin, W.L., 2016. Crustal structure of the Newer Volcanics Province, SE Australia, from ambient noise tomography, Tectonophys, 683, 382-392.

Ji, S., Li, A., Wang, Q., Long, C., Wang, H., Marcotte, D. \& Salisbury, M., 2013. Seismic velocities, anisotropy, and shear-wave splitting of antigorite serpentinites and tectonic implications for subduction zones, J. geophys. Res., 118(3), 1015-1037.

Kanamori, H. \& McNally, K.C., 1982. Variable rupture mode of the subduction zone along the Ecuador-Colombia coast, Bull. seism. Soc. Am., 72, 1241-1253.

Kendrick, E., Bevis, M., Smalley, R., Brooks, B., Barriga, R. \& Laurı, E., 2003. The Nazca - South America Euler vector and its rate of change, $J$. South Am. Earth Sci., 16, 125-131.

Kennett, B.L.N., Engdahl, E.R. \& Buland, R., 1995. Constraints on seismic velocities in the earth from travel times, Geophys. J. Int., 122, 108-124.

Kerr, A.C., Aspden, J.A., Tarney, J. \& Pilatasig, L.F., 2002. The nature and provenance of accreted oceanic terranes in western Ecuador: geochemical and tectonic constraints, J. Geol. Soc., 159(5), 577-594.

Kerr, A.C. \& Tarney, J., 2005. Tectonic evolution of the Caribbean and northwestern South America: the case for accretion of two Late Cretaceous oceanic plateaus, Geology, 33(4), 269-272.

Kerr, A.C., Tarney, J., Marriner, G.F., Klaver, G.T., Saunders, A.D. \& Thirlwall, M.F., 1996. The geochemistry and petrogenesis of the lateCretaceous picrites and basalts of Curaçao, Netherlands Antilles: a remnant of an oceanic plateau, Contrib. Mineral. Petrol., 124(1), 29-43.

Korenaga, J. \& Sager, W.W., 2012. Seismic tomography of Shatsky Rise by adaptive importance sampling, J. geophys. Res., 117(B8). doi: 10.1029/2012JB009248.

Krueger, H.E. \& Wirth, E.A., 2017. Investigating segmentation in Cascadia: anisotropic crustal structure and mantle wedge serpentinization from receiver functions, Geochem., Geophys., Geosyst., 18(10), 3592-3607.

Levshin, A., Ratnikova, L. \& Berger, J., 1992. Peculiarities of surface-wave propagation across central Eurasia, Bull. seism. Soc. Am., 82(6), 24642493.

Lin, F.C., Moschetti, M.P. \& Ritzwoller, M.H., 2008. Surface wave tomography of the western United States from ambient seismic noise: Rayleigh and Love wave phase velocity maps, Geophys. J. Int., 173(1), 281-298.

Luo, Y., Yang, Y., Xu, Y., Xu, H., Zhao, K. \& Wang, K., 2015. On the limitations of interstation distances in ambient noise tomography, Geophys. J. Int., 201(2), 652-661.

Luzieux, L.D.A., Heller, F., Spikings, R., Vallejo, C.F. \& Winkler, W., 2006. Origin and Cretaceous tectonic history of the coastal Ecuadorian forearc between $1 \mathrm{~N}$ and $3 \mathrm{~S}$ : Paleomagnetic, radiometric and fossil evidence, Earth planet. Sci. Lett., 249(3-4), 400-414.

Lynner, C., Beck, S.L., Zandt, G., Porritt, R.W., Lin, F-.C. \& Eilon, Z., 2018. Mid-crustal deformation in the Central Andes constrained by radial anisotropy, J. geophys. Res., 123, (6), 4798-4813.

Lynner, C. \& Porritt, R.W., 2017. Crustal structure across the eastern North American margin from ambient noise tomography, Geophys. Res. Lett., 44, doi: 10.1002/2017GL073500.

Meltzer, A. \& Beck, S.L., 2016. Pedernales Earthquake Aftershock Deployment Ecuador. International Federation of Digital Seismograph Networks. Other/Seismic Network. doi: 10.7914/SN/8G_2016.
Meltzer, A. et al., 2019. The 2016 Mw 7.8 Pedernales Earthquake, Ecuador: RAPID response deployment, Seismol. Res. Lett., 90(3), 1346-1354.

Moberly, R., Shepherd, G.L. \& Coulbourn, W.T., 1982. Forearc and other basins, continental margin of northern and southern Peru and adjacent Ecuador and Chile, Geol. Soc., Lond., Spec. Publ., 10(1), 171-189.

Nikulin, A., Levin, V. \& Park, J., 2009. Receiver function study of the Cascadia megathrust: evidence for localized serpentinization, Geochem., Geophys., Geosyst., 10(7). doi: 10.1029/2009GC002376.

Nocquet, J.M. et al., 2014. Motion of continental slivers and creeping subduction in the northern Andes, Nat. Geosci., 7(4), 287.

Nocquet, J.M. et al., 2017. Supercycle at the Ecuadorian subduction zone revealed after the 2016 Pedernales earthquake, Nat. Geosci., 10(2), 145.

Peacock, S.M., 1993. Large-scale hydration of the lithosphere above subducting slabs, Chem. Geol., 108(1-4), 49-59.

Porritt, R.W., Miller, M.S., O'Driscoll, L.J., Harris, C.W., Roosmawati, N. \& da Costa, L.T., 2016. Continent-arc collision in the Banda Arc imaged by ambient noise tomography, Earth. planet. Sci. Lett., 449, 246-258.

Regnier, M., Font, Y., Charvis, P., Mercerat, D., Rietbrock, A., Ruiz, M. \& Alvarado, A., 2016. Pedernales. International Federation of Digital Seismograph Networks. Dataset/Seismic Network. doi:10.7914/SN/XE_2016.

Reynaud, C., Jaillard, É., Lapierre, H., Mamberti, M. \& Mascle, G.H., 1999. Oceanic plateau and island arcs of southwestern Ecuador: their place in the geodynamic evolution of northwestern South America, Tectonophysics, 307(3-4), 235-254.

Rolandone, F. et al., 2018. Areas prone to slow slip events impede earthquake rupture propagation and promote afterslip, $S c i$. $A d v$., 4(1), doi: 10.1126/sciadv.aao6596.

Segovia, M. et al., 2018. Seismicity Distribution near a subducting seamount in the Central Ecuadorian subduction zone, space-time relation to a slowslip event, Tectonics, 37, 2106-2123.

Shao, T. et al., 2014. Antigorite-induced seismic anisotropy and implications for deformation in subduction zones and the Tibetan Plateau, J. geophys. Res., 119(3), 2068-2099.

Swenson, J.L. \& Beck, S.L., 1996. Historical 1942 Ecuador and 1942 Peru subduction earthquakes and earthquake cycles along Colombia-Ecuador and Peru subduction segments, Pure appl. Geophys., 146(1), 67-101.

Vaca, S., Vallée, M., Nocquet, J.M., Battaglia, J. \& Régnier, M., 2018. Recurrent slow slip events as a barrier to the northward rupture propagation of the 2016 Pedernales earthquake (Central Ecuador), Tectonophysics, 724, 80-92.

Vallée, M. et al., 2013. Intense interface seismicity triggered by a shallow slow slip event in the Central Ecuador subduction zone, J. geophys. Res., 118(6), 2965-2981.

van Melle, J., Vilema, W., Faure-Brac, B., Ordoñez, M., Lapierre, H., Jimenez, N., Jaillard, E. \& Garcia, M., 2008. Pre-collision evolution of the Piñón oceanic terrane of SW Ecuador: stratigraphy and geochemistry of the "Calentura Formation", Bull. Soc. Geol. Fr., 179(5), 433-443.

Wessel, P. \& Smith, W.H.F., 1999. Free software helps map and display data, EOS, Trans. Am. Geophys. Un., 72, 441.

Ye, L., Kanamori, H., Avouac, J.P., Li, L., Cheung, K.F. \& Lay, T., 2016. The 16 April 2016, M W 7.8 (M S 7.5) Ecuador earthquake: a quasi-repeat of the 1942 M S 7.5 earthquake and partial re-rupture of the 1906 M S 8.6 Colombia-Ecuador earthquake, Earth planet. Sci. Lett., 454, 248-258.

Yepes, H., Audin, L., Alvarado, A., Beauval, C., Aguilar, J., Font, Y. \& Cotton, F., 2016. A new view for the geodynamics of Ecuador: implication in seismogenic source definition and seismic hazard assessment, Tectonics, 35, 1249-1279.

\section{SUPPORTING INFORMATION}

Supplementary data are available at $G J I$ online.

Figure S1. Cross-correlation waveforms between station PORT and all other Ecuadorian stations. Waveforms are filtered between 8 and $40 \mathrm{~s}$.

Figure S2. Dispersion curves (left) and 1-D shear velocities (right) for representative grid cells in the FFA (blue) and the Manabí basin 
(MB; red) for the staring Font et al. (2013) model (dashed lines) and our final inverted shear velocity model (solid lines).

Figure S3. Interstation ray paths for all station pairs (over 5800) that yielded phase velocity measurements that passed quality controls. Several different periods are shown. Intermediate periods (12-25 s) have the densest ray coverage, with decreasing path density at the shortest and longest periods. Number of interstation paths (P.) are shown in blue.

Figure S4. Phase velocity maps at 10, 20 and 30 s periods. Regions outside the area of resolution are obscured.

Figure S5. Shear velocity maps of the Font et al. (2013) starting model that we use in this study. The Font et al. (2013) starting model varies in 3-D and includes a subducting slab and variable Moho depths in the Forearc and Andes.

Figure S6. Shear velocity maps at 10, $2030 \mathrm{~km}$ depth derived from the mantleonly (mantle velocities $\left(4.5 \mathrm{~km} \mathrm{~s}^{-1}\right)$ in the upper $50 \mathrm{~km}$ and AK135 (Kennett et al. 1995) velocities below $50 \mathrm{~km}$ ) starting model. Slab contours from Slab 2 (Hayes et al. 2018) are shown. We also present isostatic gravitational anomalies across Ecuador (Bonvalot et al. 2012).

Figure S7. Shear velocity maps at 10, 20 and $30 \mathrm{~km}$ depth derived from the 1-D crustal $\left(3.6 \mathrm{~km} \mathrm{~s}^{-1}\right.$ in the upper $26 \mathrm{~km}$, mantle velocities $\left(4.5 \mathrm{~km} \mathrm{~s}^{-1}\right)$ to $50 \mathrm{~km}$ and AK135 (Kennett et al. 1995) velocities at deeper depths) starting model. Slab contours from Slab2 (Hayes et al. 2018) are shown. We also present isostatic gravitational anomalies across Ecuador (Bonvalot et al. 2012).

Figure S8. Crosssections through our mantleonly shear velocity model as shown in Fig. 1 in the main text. Crosssection $\mathrm{A}-\mathrm{A}^{\prime}$ runs along $0^{\circ} \mathrm{N}$ and is collocated with the Pedernales earthquake rupture. Crosssection $\mathrm{B}-\mathrm{B}^{\prime}$ runs along $0.5^{\circ} \mathrm{S}$ and transects the Manabí Basin. Transect $\mathrm{C}-\mathrm{C}^{\prime}$ parallels $1.5^{\circ} \mathrm{S}$ and samples the FFA. The $\mathrm{D}-\mathrm{D}^{\prime}$ crosssection highlights the Forearc of the Ecuadorian margin. It traverses the Manabí basin in the north and the FFA in the south. Aftershock events within $\sim 10 \mathrm{~km}$ of each crosssection are also shown as circles. Figure S9. Crosssections through our 1-D crustal shear velocity model as shown in Fig. 1 in the main text. Cross-section $\mathrm{A}-\mathrm{A}^{\prime}$ runs along $0^{\circ} \mathrm{N}$ and is collocated with the Peder-nales earthquake rupture. Cross-section $\mathrm{B}-\mathrm{B}^{\prime}$ runs along $0.5^{\circ} \mathrm{S}$ and transects the Manabí Basin. Transect $\mathrm{C}-\mathrm{C}^{\prime}$ parallels $1.5^{\circ} \mathrm{S}$ and samples the FFA. The D$\mathrm{D}^{\prime}$ crosssection highlights the Forearc of the Ecuadorian margin. It traverses the Manabí basin in the north and the FFA in the south. Aftershock events within $\sim 10 \mathrm{~km}$ of each crosssection are also shown as circles.

Figure S10. Checkerboard resolution tests of our inversion. Checkers represent \pm 5 per cent velocity perturbations with a grid size of $0.75^{\circ}$.

Figure S11. Checkerboard resolution tests of our inversion. Checkers represent \pm 5 per cent velocity perturbations with a grid size of $1.25^{\circ}$.

Figure S12. Sensitivity kernels of Rayleigh waves through the FFA. Normalized sensitivities are shown for the periods used in this study coloured by period.

Figure S13. Misfit plots between phase velocities predicted by our final model and the observed phase velocities for the various periods used in this study.

Figure S14. Misfit reduction between our final model and a homogeneous $4.0 \mathrm{~km} \mathrm{~s}^{-1}$ starting model for the periods used in this study. Regions like the FFA that are near $\sim 4.0 \mathrm{~km} \mathrm{~s}^{-1}$ show low misfit reduction because it is similar to the homogeneous model velocity.

Please note: Oxford University Press is not responsible for the content or functionality of any supporting materials supplied by the authors. Any queries (other than missing material) should be directed to the corresponding author for the paper. 